\title{
Changing Function of the Forest and Exploitation in East Coast Sumatra in Colonial Period
}

\author{
Azmi Fitrisia ${ }^{*}$, Ernawati $^{2}$, and Zul Asri ${ }^{3}$ \\ ${ }^{123}$ Universitas Negeri Padang, Kampus UNP Air tawar Jl. Prof Hamka, Padang, Indonesia \\ "Corresponding author. Email: azmifitrisia@fis.unp.ac.id
}

\begin{abstract}
This article discusses the changes that occurred in the forests of the east coast of Sumatra during colonial period. An important question in this article is why has it been a change to the functioning of the forest?. What has the consequences of the change? This study uses the basic methods of history: heuristic, criticism, interpretation and historioghraphy. This research has used colonial documents and archives. The secondary data have been magazines and newspapers. The results of this research is the changes function of east coast Sumatra forest becaused colonial. The colonial successed to controlling the region. The defeat of the kingdom on the east coast Sumatra made it easy for the colonials to carry out a centralized bureaucratic system and the application of the capitalist economic system. Since 1871 the east coast of Sumatra until Indonesia independence expanded the plantations ranging from tobacco, rubber, etc. For the benefit of plantations and industry also began to be built office housing and road as well as railway. The area, which was formerly a forest, has been transformed into a destination for colonial economic benefits. It impacted the condition of forests, rivers, coastal areas and the sea. Most of the forest has been reduced which has an impact on river erosion and superficiality. Most of the rivers that were once a means of transportation are difficult and can no longer be sailed. Similarly, this shallowing has had an impact on the dwindling breed and number of fish that were once very easy to find on the seafront waters of the Malacca Straits.
\end{abstract}

Keywords: changing fuction, forest, exploitation, east coast Sumatra, colonial period

\section{INTRODUCTION}

This paper mains to describe and analysis about east coast Sumatra forest. It's Aceh, east Sumatra, Riau and Jambi. The important question is why has it changed of forest function? How was the impact? The research is using the approach of history forest. The approach has analysed the diacronical process of the fact forest changing and the impact. The changing of forest was impacted of political economy decision maker of goverment. It's new in history science. There is not paper about history of forest ecology. Many paper has viewed geography, economy, sociology and antropology. It has written by scientis likes I Nyoman Burjaya[1], Bruno Verbist dan Gamal Pasya[2], Esther Mwangi, Andrew Wardell[3], Amogne Asfaw Eshetu[4], Danny L. Fry, Jamie M Lydersen, Richard Everett, Scott L. Stephens[5], Sango Mahanty, Jane Gronow, Mike Nurse and Yam Malla [6]. Virginia H. Dale, LindaI A. Joice, Steve Mcnulty, Ronald P. Neilson, Matthew P. Ayres. Micheal D. Flannigan, Paul J Hanson, Lloyd C. Swanson, Brian J. Stocks and B. Michael Wotton[7], James M. Dye.r[8] Treena Burgess and Michael J.Wingfield[9], James Fairhead, Melissa Leach[10]. J. Jennifer, A. Hoss, et.al[11] Kuralay Mazarhanov, Arailym Kopabayeva,
Nesibe Kose, Ünal Akkemik [12], Jorund Rolstad,Yivali Blanck, and Ken Olaf Storaunet[13], Collin Haffey, Thomas D. Sisk, Craig D. Allen, Andrea E. Thode, and Ellis Q. Margolis[14], Henri, Luchman Hakim, and Jati Batoro[15]. Chandra Giri, Pius Akindele Adeniyi[16], Jed O. Kaplan, et.all[17]. Philipe M. Fearnside[18]. J. P. A. Shatford, D. E. Hibbs, and K. J. Puettmann, Conifer[19], Adriana Sulakand Lynn Huntsinger [20], Deborah K. Kennard[21] Robin. L Chaz don,et.al.[22] Cecil C. Konijnendijk et.a.[23] The article is case in Indonesia, southwest America, Amazon-Brazilia, Sierra Nevada California, West America, northeast America, Norwegia-Europe, Burabai Kazakhstan (Africa), Ethiopia, Guinea (West Africa), Bolivia (Africa). Comparation study of the forest city in North America and Europe[24] help to understand category of changing of forest to city in east coast Sumatra. The article of Ethiopia forest become paradigm to integration between economic development and forest's management.[25] Ethiopia had differenced motivation to manage the forest in half of century. The management policy of forest had put economic forming than protection of ecosystem forest. In the east coast of Sumatra is likely to occur in colonial period. To the south Hemisphere has began 
reboisation with the industry forest pattern to global. The alert problem is deseart.[26] To relation the forest with pests and diseases has interested. But it is less important to east coast Sumatra forest. The east coast of Sumatra has analysis policy of economy politic The changing was looked goverment policy. The article about erosion in Europe had written.[27] Erotion in Europe has began prehostoric. The prehistoric man done forest to agriculture. The other research is firing of the pinus forest in Burabai Kazakhstan.[28] Firing was occured in 1759, $1779,1997,1824,1933,1852$, dan 1871. It had inspirition to analysis the east coast Sumatra forest. The pinus forest was fired in Norwegia.[29] likes the written by Collin(2018). The firing of forest in southwest United State especially Klamath- Siskiyous.[30] Recovery of forest in California and Orean had needed between 9-19 years. Peter Mountain Virginia-America.[31] The forest in east coast Sumatra has analysis the changing forest in history politic economy paradigm. The study of forest had done in North America.[32] Sierra Nevada has dry forest. The changing of forest was caused bobbin wood. The east coast Sumatra research has analysis composition, ecology structure, and the forest function. Philip. M.[33] Erosion of Brazil-Amazone forest has impact to biota, product, water circulation and global warming. The goverment give some landraform policy to prepare forest condition such credit, subsidi and tax deduction. All of relevan study has used to conseptual framework. To analysis the fact of history ecology of Malacca Traits especially forest resources of east coast of Sumatra.

\section{MATERIAL AND METHOD}

The research is using history method that consist four stages heuristic, critic, interpretation and historiography.[34] The sources of research has could in Indonesia, Malaysia an Singapore especially in National Library of Singapore. It used archive, magazine, journal and others. The critic procesed had setted. All of data is original allthough of it old and fragil. Interpretation of fact has helped by conceptual framework. In this step has done to relation and compare of fact. The last processed is generalisation in historioghraphy.[35]

\section{RESULT AND DISCUSSION}

Sumatra agreement between British and Dutch in 1871 had changed politic structure in east coaast Sumatra.[36] The agreement was change power between Dutch and British. British was lost Bengkulu and move to Semenanjung Tanah Melayu (Malaysia). Dutch had been power in East Coast Sumatra without Aceh. Dutch was doing the sentralistic modern birocracy after Sumatra Agreement Sentralistic birocracy had central in Batavia with Goevernoer General is led. The east coast Sumatra is one of residentie with Bengkalis that was central of province.[37] East Coast Sumatra Residentie was devided to Afdeeling (city) Bengkalis, Siak Sri Indrapura, Palalawan, Pinang, Panei, Bila, Kwalu, Asahan, Tandjong, Si Pare-Pare, Pagarawan, Deli (PadangBadagei), Serdang, Langkat and Tanjung Pinang. Bagan Siapi Api is central city of Afdeeling Bengkalis.[38] The kingdom of Siak, Deli, Serdang, Langkat, Batu Bara, Asahan had falling by contract that made by colonial.[39] The contract was less of power the east coast kingdom to culture activity.[40] The nobelity was slowly that was not received 'tribute'. Colonial policy that Siak Kingdom received the salary more than $5 \%$ procent from tax and the force labour of paeople.[41] Besluit (government regulations) van Het Inlandsche Zelfbestuur van Siak tahun 1919 explanationed that the power of Siak kingdom and employees was less.[42]

The weakly politics of Siak Kingdom had given opportunity the colonial to implementation of capitalisme economic policy. The area of east coast Sumatra had opened to export plantation likes tabacco, rubber and others. The forest of east coas Sumatra had fast change.[43] Mach of the forest had cut down to plantation, land road, railway, oil industry, port and resident. It had impacted to resouces an ecosystem.

The plantation had began Yacobus Nienhuys in year 1863. He opened the forest to tabacco plantation in Deli. In year 1869, Deli Maatchapij opened the forest to 23 tabacco plantation. In year 1873 , production of tabacco growth to 39.280 kilograms with price $f 2,500,000$. In year 1881, production of tabacco increased to 82,356 pek $(576.492 \mathrm{~kg})$ that had sold $f 16,750,000$ in Ducth. The important export from Sumatra was tabacco.[44]

Exploitation of forest had done in other places in east Sumatra. Forest was changed to coffee plantation, coconut, tea, rubber, palm, and uncaria Many of coffee plantation was developed in Serdang and Batubara area. It was caused that tabacco plantation failed. There was seven coffee plantation was opened too in Serdang in year 1880 . There is others places of forest in east Sumatra was cut to coffee plantation. But only in Serdang area was successfull.[45] The plantation of uncaria, palm, rubber, and sago was suitable in Asahan. In year 1890 was cut $200 \mathrm{~km}$ the forest for plantation. It began Tebing/Asahan river to Batangan di North.[46] In Simalungun was planted tea. It opened the 14 plantationin year 1916. The tea plantation resulted $1,500,000 \mathrm{~kg}$. Before, It was exported copra estimed $25,000,000 \mathrm{~kg}$ in year 1913 
Table 1. The Growth of Plantation in East Coast

Sumatra

\begin{tabular}{|c|c|c|}
\hline Year & Varieties & plantatioan/area \\
\hline 1963 & Tabacco & 23 (Deli) \\
\hline 1880 & Coffee & 7 (Serdang) \\
\hline & $\begin{array}{c}\text { Rubber, palm, } \\
\text { uncaria }\end{array}$ & $\begin{array}{c}200 \mathrm{~km} \text { (Asahan, } \\
\text { Batangan) }\end{array}$ \\
\hline 1911 & rubber & $6.070 .290 \mathrm{~km} 2$ \\
\hline 1912 & rubber & $222.577,3 \mathrm{~km} 2$ \\
\hline 1913 & rubber & $906.946,64 \mathrm{~km} 2$ \\
\hline 1916 & tea & $14 /$ Simalungun \\
\hline 1918 & ficus & $24.281,16 \mathrm{~km} 2$ \\
\hline & & \\
\hline
\end{tabular}

Sources: Processes from G.W. Prothero, 1920, Thee Kian Wie, 1969, Tengku Lukman Sinar, 1971

It was not exactly area of forest was cut to plantation in east coast Sumatra. The table 1 was a less fact.[47] Between year 1913-1918 more than before. After a year 1918 had opened 7,000 hectares in Deli, Serdang and Langkat. In year 1941, The plantation company developted until 180,000 hectares.[48] The forest was cutted to plantation estimate 615,000 hectares between year 1911-1941.

The forest had changed to plantation. In east Sumatra was written that rubber began to plant in 1885 . It was planted 10,000 rubber tree in year 1892. The rubber tree was widespread in east Sumatra in year 1906.[49] The tea plantation was more recent than rubber tree. It was year 1898. Begin year 1863 had planted many of export crops that means tropica run forest was lost to plantation. It had impact to soil structure and rivers bed. The opening of forest in colonial period used burn slash system. It had impact to soil density, changes in the top layer of soil and loss of soil humus substances. So, opening of forest caused weakly and erosion of river cliffs at places. The area of river became deposits places. The rubber tree that eged 23 year had deposits $25 \mathrm{~m} 3 / \mathrm{km} 2$ in river bed. Althought tea and coffee had not biggest impact but open ground outside the tree that incrased water and erosion. Rubber and palm had incrase water estimed $10 \%$ in year.[50]

Export tabacco needed most of nipa leaves. It caused exploitation nipa in coast Deli, Langkat, Panei, Bila, Asahan, and Siak. Nipa leaves were needed to roof shed and tabacco drying places. The cutting nipa tree as long as coast of east coast Sumatra had bad impact to the structure of mangrove forest.
Table 2. Export of Wood in Afdeeling Bengkalis 19101927

\begin{tabular}{|l|l|l|l|l|l|l|}
\hline No & Year & $\begin{array}{c}\text { Bea } \\
\text { ms }\end{array}$ & $\begin{array}{c}\text { Fire } \\
\text { woo } \\
\text { d }\end{array}$ & $\begin{array}{c}\text { Sa } \\
\text { w } \\
\text { wo } \\
\text { od }\end{array}$ & $\begin{array}{c}\text { Charc } \\
\text { oal } \\
\text { wood }\end{array}$ & gld \\
\hline 1. & 1910 & 96 & - & - & - & 100,385 \\
\hline 2. & 1911 & 96 & - & - & - & 100,085 \\
\hline 3. & 1912 & 102 & 42 & 8 & 40 & 117,616 \\
\hline 4. & 1913 & 97 & 46 & 8 & 62 & 180,883 \\
\hline 5. & 1914 & 93 & $\begin{array}{l}37 \\
(\mathrm{p})\end{array}$ & 10 & $71(\mathrm{p})$ & 100,435 \\
\hline 6. & 1927 & 450 & $\begin{array}{l}100 \\
\mathrm{~T}\end{array}$ & & $\begin{array}{l}37.50 \\
0 \mathrm{~T}\end{array}$ & $\begin{array}{l}>1,000,0 \\
00\end{array}$ \\
\hline 7. & 1928 & teak & & & & \\
\hline
\end{tabular}

Sources: Processes from (G. W. Prothero, 1920),

Bobbin wood disturbed trees in the forest. But export of the bobbin wood was developed in year 1914 . Cutting of the forest had exactly in 37 places and charcoal wood in 71 places in east coast Sumatra.[51] The forest was disturbing for infrastucture.[52] At began year 1880 was made highways by Deli Maatschappij in east coast Sumatra. Deli Spoorweg Maatschappij was builded in year 1883. At year 1915 the colonial developed highways as long as 6,200 km.[53] Until tha year 1920 had build 500,000.[54]

If we are analysis that it is the forestation. The change of forest to became plantation had water problem as long as season. It was most effect to nature from build of highway and railway. Because the forest was change with iron and cement. The higways and railway was artificial nature. It could not holding water in the ground. The big trees have roots that can withstand water in the soil. The highways and railways had eliminate fuction and the disturbing of natural ecosystem

In year 1883, oil industry was open in Telaga Said Langkat estimate The place was estimate $70 \mathrm{~km}$ from Pangkalan Brandan city.[55] Colonial Belanda was build Bagan Siapi Api port in the year 1901 and Belawan port to export the production of east coast Sumatra in year 1922. 
Picture 1. Port, Station, Railway, City and Other Developing of East Coast Sumatra in 19 century

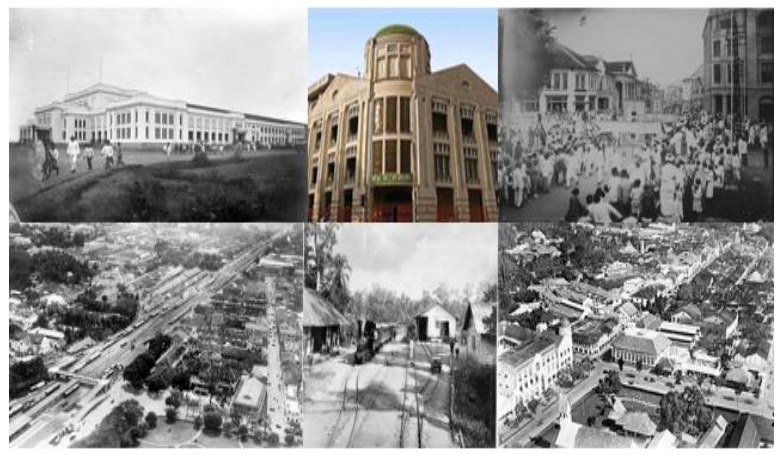

Sources: KITLV and Tropenmuseum

The opening of forest to plantation, oil industry, port, station and other facilities caused incrasing of people. East Sumatra had become 1,197,554 in year 1920. It was consist of indigenous $1,042,930$, chinese migrants 154,750, Arab migrants 400, Eropean 7,882, and Others east Asia 11,592.[56] The people of east coast Sumatra had become 1,400,000.[57] The composition of people were laborer in plantation, fishery, and industry. In year 1916 was increase laborer more 198,093. It consist the 43,689 Chineses migrants, male local migrants of Java island, 45,895 femail local migrants of Java island, 3,025 from India, and others 987.[58] Java local migrants become ahead of Chinese migrants. Migrants's Jawa were plantation area in year 1880. [59] The government calculation of the population was everage $34 / \mathrm{km}$ in year 1920.[60] It was very different with year 1823 where the people of East coast Sumatra only 350,000.[61] It means the east coast people 4 times more in colonial period. Chinese migrants was high than indigenous in the east coast Sumatra in year 1930. The comparison was $41 \%$ indigenous and $43,1 \%$ chinese migrants.[62]

\section{CONCLUSION}

In East coast Sumatra had change the forest function. It was caused the colonial economic policy. The capitalism planning of colonialist had open the forest to economic export likes plantation and industry. To support of it that colonial build the railways, highways, port, station and others city facitilies. Most of the forest was cut to needing economic export. The forest was also cut to export the wood likes chorcoal fire wood, beams and others.

The exploitation of the forest had less of the rain tropical and mangrove forest. The other consequences was likes erosion, rivers superficiality. Many of the forest in many island in east coast Sumatra was bald like Bengkalis, and Rupat forest. The others impact of cutting the forest was rivers in east Coast Sumatra become suferficial. Rokan and Siak rivers was example of problematic that caused cutting of the forest. Rokan River was difficult to pass of large ships.

\section{ACKNOWLEDGMENTS}

We would like to thank all those who have helped with this research. Especially the Rector of Universitas Negeri Padang (UNP) who has supported the funding of this research through LP3M UNP. So also thank you for the archives and library employees in Indonesia, Malaysia and Singapore.

\section{REFERENCES}

[1] I Nyoman Nurjaya. (2005). "Sejarah hukum pengelolaan hutan di Indonesia", in Journal Jurisprudence, Vol.2, No.1, March, 35-55.

[2] Bruno Verbist, Gamal Pasya. (2004). "Perspektif sejarah status kawasan hutan: konflik dan negosiasi sumberjaya, Lampung Barat-Propinsi Lampung", in Agrivita Journal. Vol. 26. No.1. March, 20-29.

[3] Esther Mwangi Andrew Wardell. (2012). "Multilevel governance of forest resources", in International Journal of the Commons. Vol. 6, No. 2 August, pp. 79-103.

[4] Amogne Asfaw Eshetu, (2014). "Forest resource management systems in Ethiopia: historical perspective", in International Journal of Biodiversity and Conservation. Vol. 6 (2) February. pp.121-131.

[5] Danny L. Fry, Jamie M Lydersen, Richard Everett, Scott L. Stephens, (2017). "Impacts of different land management histories on forest change", in Journal Ecological Applications, 27(8), pp. 24752486.

[6] Sango Mahanty Jane Gronow, Mike Nurse and Yam Malla, (2006). "Reducing povertythrough community based forest management in Asia", in Journal of Forest and Livelihood 5(1) February, pp.77-89.

[7] Virginia H. Dale, LindaI A. Joice, Steve Mcnulty Ronald P. Neilson, Matthew P. Ayres. Micheal D. Flannigan, Paul J. Hanson, Lloyd C. Swanson, Brian J. Stocksand B. Michael Wotton.( 2001). "Climate change and forest disturbances", in Bio One Journal. September 2001/ Vol.51. No. 9. pp 723-734.

[8] James M. Dyer. (2006). "Revisiting the deciduous Forests of Eastern North America", in Journal Bioscience, April. Vol.56 No.4.pp.340-352.

[9] Treena Burgess and Michael J. Wingfield. (2001). "Exotic pine forestry in the Southern Hemisphere: A brief history of establishment and quarantine practices", in Southern African Forestry Journal No. 192, November. pp78-84.

[10] James Fairhead, Melissa Leach. (1995). "False forest history, complicit social analysis: rethinking some West African environmental narratives", in 
Journal World Development. Vol. 23, No. 6, pp.1023-1035.

[11] Jennifer, A. Hoss, etc. (2008). Fire History of a tempreture forest with endemic fire-dependen therb", in Journal Physical Geography, 29,5 pp 244-251

[12] Kuralay Mazarhanov, Arailym Kopabayeva, Nesibe Kose, Unal Akkemik. (2017). The first forest fire history of the Burabai Region (Kazakhstan) from treerings of $\mathrm{p}$ inus sylvestris",in Turki Agric For. 4

[13] Jørund Rolstad,Yiva-li Blanck, and Ken Olaf Storaunet. (2017). "Fire history in a western Fennoscandian boreal forest as influenced by human land use and climate", in Ecological Monographs 0(0),2017, pp.1-27.

[14] Collin Haffey, Thomas D. Sisk, Craig D. Allen, Andrea E. Thode, and Ellis Q. Margolis. (2018). "Limits to Ponderosa pine regeneration following large high-severoty forest in the United State Southwest" Fire Ecology. Volume 14, Issue1, pp.143-163.

[15] Henri, Luchman Hakim, and Jati Batoro. (2018). "Kearifan lokal masyarakat sebagai upaya konservasi hutan Pelawan di Kabupaten Bangka Tengah, Bangka" in Journal Ilmu Lingkungan, 16(1), pp.49-57.

[16] Chandra Giri, etc. Pius Akindele Adeniy "Distribution and dinamics of mangrove forest in South Asia", in Journal of Environmental Management. journal homepage: www elsevier. com /locate/jenvman. pp1-9

[17] Jed O. Kaplan, et.al. (2009). "The prehistoric and preindustrial deforestation in Europa", Quaternary Science Reviews. 28. pp 3016-2034

[18] Philipe M. Fearnside. (2005). "Deforestation in Brazilian Amazonia: history, rates, and consequences", in Conservation Biology, Volume 19, No. 3, June. pp 61-69.

[19] J. P. A. Shatford, D. E. Hibbs, and K. J. Puettmann, Conifer. (2007). "Regeneration after forest firein the Klamath-Siskiyous: how Much, How Soon?", in Journal of Forestry April/May. Pp. 139-147.

[20] Adriana Sulakand Lynn Huntsinger. (2012). "Perceptions of forest health among stakeholders in an adaptive management projectinthe Sierra Nevada of California", in Journal of Forestry. Month http:// dx.doi.org /10.5849 /jof. 12-004 pp 1-6

[21] Deborah K. Kennard. (2002). "Secondary forest succession in a tropical dry forest: patterns of development across a 50-year chronosequence in lowland Bolivia", in Journal of Tropical Ecology 18:53-66

[22] Robin.L Chazdon. (2016). "Whenisa forest a forest? Forest concepts and definitionsin theera of forest and scape restoration", Ambio A Journal of he Human

Environment $\cdot$ March2016.Springerlink.comwww.k va.se/en.p.1

[23] Cecil C. Konijnendijk et.al. (2006). "Difining urban forestry: a comparative North America and Europe. In Urban Forestry and Urban Griining, 4, pp 93103.
[24] Sango Mahanty, Jane Gronow, Mike Nurse and Yam Malla. (2006). "Reducing poverty through community Based Forest Management in Asia", in Journal of Forest and Livelihood 5(1) February, pp 77-89.

[25] Amogne Asfaw Eshetu, (2014). "Forest resource management systems in Ethiopia: historical perspective", in International Journal of Biodiversity and Conservation. Vol. 6 (2), February, hlm 121-131

[26] Virginia H. Dale, LindaI A. Joice, Steve Mcnulty, Ronald P. neilson, matthew P. Ayres. Micheal D. Flannigan, Paul J. Hanson, Lloyd C. Swanson, Brian J. Stocks and B. Michael Wotton. (2001). "Climate Change and Forest Disturbances", in Bio One Journal. September. Vol. 51 No. 9. pp 723734.

[27] Ed. O. Kaplanetc. (2009). "The prehistoric and preindustrial de forestation in Europa", Quaternary Science Reviews 28. p.3016.

[28] Danny L. Fry, Jamie M Lydersen, Richard Stephens,. Everett, Scott. (2014). "Impacts of different land management histories on fores change", in Journal Ecological Application 27(8)

[29] Kuralay Mazarhanov, Arailym Kopabayeva, Nesibe Kose, Ünal Akkemik. (2017). The first forest fire history of the Burabai Region (Kazakhstan) from treerings of pinus sylvestris", in Turki Agric For. 4.

[30] P. A. Shatford, D.E. Hibbs, and K. J.Puettmann, Conifer, (2007). "Regeneration after forest firein the Klamath-Siskiyous: How Much, How Soon?", in Journal of Forestry April/ May. pp 139.

[31] Jennifer, A. Hoss, etc, (2008). Fire history of a tempreture forest with endemic firedependentherb", in Journal Physical Geography, 29, 5. pp 244 - 241

[32] Esther Mwangi, Andrew Wardell. (2012). "Multilevel governance of forest resources", in International Journal of the Commons Vol. 6, No 2 August. pp 79-103.

[33] Philipe M. Fearnside. (2005). "Deforestation in Brazilian Amazonia:History, Rates, and Consequences", in Conservation Biology, Volume 19, No. 3, June .pp. 61-69

[34] Garraghan, G. (1957). A guide to historical method. New York: Fordham University Press, pp. 33-34.

[35] Sartono Kartodirdjo. (1990). Pendekatan ilmu sosial dalam metodologi sejarah. Jakarta: Gramedia PustakaUtama, pp. 90-91

[36] Anthony Reid, 1909. The Contest for North Sumatera Aceh, The Netherlands and Britain 1858. 1898. Kuala Lumpur Singapura London and London : Oxford University Press New York, University of Malaya Press, pp. 52-78

[37] Tengku Luckman Sinar. (1971). Sari sejarah Serdang Jilid 1. Medan: Kerjasama dengan Ikatan Keluarga Serdang dan Lembaga Penelitian Hukum Universitas Sumatera Utara. p. 174.

[38] Tim P \& K, (1983). Sejarah Kebangkitan Daerah Riau. Pekanbaru : P \& K, pp. 28-30.

[39] Tate, D. J. M. (1979). The Making of Modern SouthEast Asia. Volume 1. The European Conquest. 
Kuala Lumpur: Oxford University Press. p. 250

[40] G. Stibbe, (1917). ENI. Leiden : N.V.V.H. E. J. Brill-'S Gravenhage Martinus Nijhoff, pp.141-145

[41] T.J. Tideman, (1935). "Land en Volk van Bengkalis" in. TNAG. Deel. LII, pp. 797.

[42] Tim P \& K, 1983. Sejarah Kebangkitan Daerah Riau. Pekanbaru : P \& K, hlm. 28-30.

[43] Kehding, F, (1965). "Occasional Note : Notice of Book”. in. JSBRAS, No. 17. p.

[44] Karl J. Pelzer, (1985). Toean Keboen dan Petani, Politik Kolonial dan Perjuangan Agraria di Sumatra Timur 1863-1947. Trj. J. Rumbo. Jakarta: Sinar Harapan, pp. 51-64.

[45] Tengku Luckman Sinar, (2009). Sejarah Medan Tempo Doeloe. Tanpa penerbit. pp. 25.

[46] Thee Kian Wee. (1977). .Plantation Agriculture and Exsport Growth an Economic History of East Sumatera, 1863-1942. Tanpa tempat terbit : LEKNAS LIPI, pp. 1-43

[47] G. W. Prothero, (1920). Sumatra. London: H.M. Stationery Office, pp. 39.

[48] Karl. J. Pelzer, (1978). Planter and Peasent Colonial Policy and the Agrarian Struggle in East Sumatera 1863-1947. 'S Gravenhage-Martinus Nijhoff., p. 39

[49] Karl. J. Pelzer, (1978). Planter and Peasent Colonial Policy and the Agrarian Struggle in East Sumatera 1863-1947. 'S Gravenhage-Martinus Nijhoff., p.39.

[50] Lawrence S. Hamilton-Peter N. King. (1988). Daerah Aliran Sungai Hutan Tropika:Tanggapan Hidrology dan Tanah Terhadap Penggunaan atau Konversi. Trj. Krisnawati Suryanata. Yogyakarta:
Gadjah Mada University Press. pp. 99.

[51] G. W. Prothero, (1920). Sumatra. London: H.M. Stationery Office, p. 44.

[52] Rusli Amran, 1988. Padang Riwayatmu Dulu. Jakarta: Yasaguna. p.12.

[53] G. W. Prothero, 1920. Sumatra. London: H.M. Stationery Office, p. 20.

[54] Edi Sumarno, Ogos (2006). "Mundurnya Kota Pelabuhan Tradisional di Sumatera Timur Pada Periode Kolonial". Dlm. Historisme, no. 22/ Tahun XI, p. 3.

[55] G. W. Prothero, (1920). Sumatra. London: H.M. Stationery Office. p.49.

[56] Tengku H.M. Lah Musni, 1975. Lintasan Sejarah Peradapan dan Budaya Penduduk Melayu Pesisir Deli Sumatera Timur. Medan: B.P. p.87.

[57] Daniel Perret, (1995). Kolonialisme dan Etnisitas. Batak danMelayu di Sumatra Timur laut. Bogor. Perpustakaan Populer Gramediia, p.20

[58] G. Stibbe, (1917). ENI. Leiden : N.V.V.H. E. J. Brill-'S Gravenhage Martinus Nijhoff, p.141-145

[59] Anthony Reid, (2011) Menuju Sejarah Sumatra: Antara Sejarah Indonesia dan Dunia. Jakarta: KITLV danYayasan Obor, p. 220

[60] Resident Sumatera Timur. (1905) Ekspor Impor Sumatra Timur, p 18-21. John Anderson, (1971). Mission to The East Coast Sumatra 1823. Kuala Lumpur: Oxford University Press, p. 201

[61] John Anderson, 1971. Mission to The East Coast Sumatra 1823. Kuala Lumpur: Oxford University Press, p. 201

[62] T.J. Tideman, 1935.."Land en Volk van Bengkalis" in. TNAG. Deel. LII. p. 797 